\title{
THE CENSUS OF MARINE LIFE: UNDERSTANDING MARINE BIODIVERSITY PAST, PRESENT AND FUTURE
}

\author{
EL CENSO DE LA VIDA MARINA: COMPRENDIENDO LA \\ BIODIVERSIDAD MARINA - PASADA, PRESENTE Y FUTURA
}

\author{
Ronald K. O’Dor \& Kristen Yarincik \\ Consortium for Oceanographic Research \& Education, \\ 1755 Massachusetts Ave. NW, Washington, DC 20036
}

\begin{abstract}
As an overview provided to the South American Workshop on Marine Biodiversity, this article presents the unique collaborative approach of the Census of Marine Life (CoML) to increasing our knowledge of the abundance, distribution and diversity of marine life throughout the world's oceans. Five elements comprise the foundation of the research program, providing information and methods useful for enhancing our understanding of marine biodiversity, both historically and today, and making sound predictions of biological diversity in the future. (1) A series of initial field projects will demonstrate techniques or technologies to be applied to future studies. Some of these will test new technologies in well-known areas of the ocean, but most will take place in poorly known regions where both new and existing methods of surveying marine life will yield new information. (2) The Ocean Biogeographic Information System will make CoML and independent biological data accessible by serving as a single entry point to a distributed federation of databases. It will also provide tools for all users to create visualizations of the distribution and abundance of organisms together with environmental parameters in three dimensions. (3) Through the History of Marine Animal Populations, the historical component of the CoML, biologists and marine historians will mine and analyze historical records dating before human impact on the ocean became significant. (4) Exploring and documenting the multitude of ocean life accessible today requires advanced technology, and the CoML is working with the Scientific Committee on Oceanic Research Working Group on New Technologies for Observing Marine Life to move recent technological advances for observing marine life into the field. (5) The Future of Marine Animal Populations program will demonstrate and develop modeling approaches to hindcasting and forecasting changes in global biodiversity in response to fishing, pollution, and climate change.
\end{abstract}

KEYwords: Marine biodiversity, Census of Marine Life, CoML.

\section{RESUMEN}

Este artículo presenta el enfoque cooperativo único del Censo de la Vida Marina (CoML) para aumentar nuestros conocimientos de la abundancia, distribución y diversidad de la vida marina en los océanos del mundo como una vista general que fue presentado al Taller Sudamericano de Biodiversidad Marina. La base del programa de investigación está basada en cinco elementos, los cuales proveen información y metodologías que son útiles para mejorar nuestro entendimiento, histórico y actual, de la biodiversidad marina y predicen la biodiversidad a futuro de forma confiable. (1) Una serie de proyectos iniciales en terreno demostrarán las técnicas o tecnologías a aplicar en estudios futuros. Algunos de estos proyectos comprobarán nuevas tecnologías en áreas del océano que son bien conocidas, pero la mayoría de los proyectos serán realizados en regiones poco conocidas, donde la aplicación de metodologías para el estudio de la vida marina, tanto nuevas como existentes, rendirán nueva información. (2) El Sistema de Información Biogeográfico del Océano hará que los datos de CoML y otros datos independientes estén disponibles al funcionar 
como un punto de entrada único para una federación distribuida de bases de datos. Además, proveerá herramientas para que todo usuario pueda crear visualizaciones de la distribución y abundancia de los organismos en conjunto con los parámetros ambientales en tres dimensiones. (3) A través de la Historia de Poblaciones de Animales Marinos, el componente histórico del CoML, los biólogos e historiadores marinos extraerán y analizarán los registros históricos desde antes que el impacto humano en el océano fuera significante. (4) Hoy en día, la exploración y documentación de la multitud de vida oceánica accesible requiere tecnología avanzada. A tales fines, el CoML trabaja en conjunto con el Comité Científico del Grupo de Trabajo de la Investigación Oceánica en Tecnologías Nuevas para la Observación de la Vida Marina con el fin de colocar en terreno los avances tecnológicos en la observación de la vida marina. (5) El programa Poblaciones de Animales Marinos a futuro demostrará y desarrollará los enfoques de modelaje para revelar, hacia el pasado y el futuro, los cambios en la biodiversidad global como respuesta a la pesca, la contaminación y el cambio climático.

Palabras Claves: Biodiversidad Marina, Censo de la Vida Marina, CoML.

\section{INTRODUCTION}

Throughout the development of modern society, the oceans have been routinely treated as limitless sources and sinks for human consumption and waste. By the end of the $20^{\text {th }}$ century, it had become clear that the oceans were changing in response to intense fishing, pollution, and climate change (NRC 1995). Continuous discoveries of new species and habitats highlighted the lack of basic information required to fully understand the more complex interactions in marine ecosystems. Recognition that science has sampled less than $0.1 \%$ of the volume of the oceans led to the convening of a series of workshops focused on the question of whether it is possible to document what lives there, so that the changes can be monitored and understood (Ausubel 1999). The outcome was a recommendation for a comprehensive international research program called the Census of Marine Life (CoML). The purpose of the CoML is to assess and explain the diversity, distribution and abundance of marine organisms throughout the world's oceans (Ausubel 2001). It is organized around the questions: What did live in the oceans? What does live in the oceans? What will live in the oceans?

The oceans occupy over $70 \%$ of the Earth's surface and $90 \%$ of the volume of its biosphere and pose a huge challenge for documenting the diversity of life that exists there. The two hundred international scientists who participated in the workshops, however, agreed that new technologies available at the turn of the millennium have made it plausible to ask and answer these questions. In addition, awareness of the need for more information has already led to the development of distributed individual efforts by governments, industry and international monitoring and observing organizations. Therefore, the key to conducting a global census of life in the oceans will lie not only in the generation of new studies but also in cooperation, collaboration, and a willingness to share by all users of marine biological information.

Based on these recommendations, the Census of Marine Life was launched in 2000. Although the precision of the census cannot be predetermined and costs are estimated to be in the billion-dollar range, major advances are possible within a decade that can contribute usefully to the knowledge base necessary to manage an environment under increasing pressure. The CoML's unique niche among global marine research programs comes from its focus on diversity at the higher levels of food webs, the consequent requirement for extensive taxonomic expertise to characterize undescribed species, and special interests in timelines extracted from nontraditional sources in the field of marine science. The detailed planning approach integral to the program is centered on assembling what is known, assessing what is knowable and, therefore, avoiding barriers to our goals by seeking the unknowable.

\section{ELEMENTS OF THE PROGRAM}

A group of eleven senior marine scientists from around the world forms the Scientific Steering Committee (SSC) for the Census of Marine Life. The SSC agreed upon the steps necessary for the initiation of a successful program with far-reaching impact on our understanding of marine 


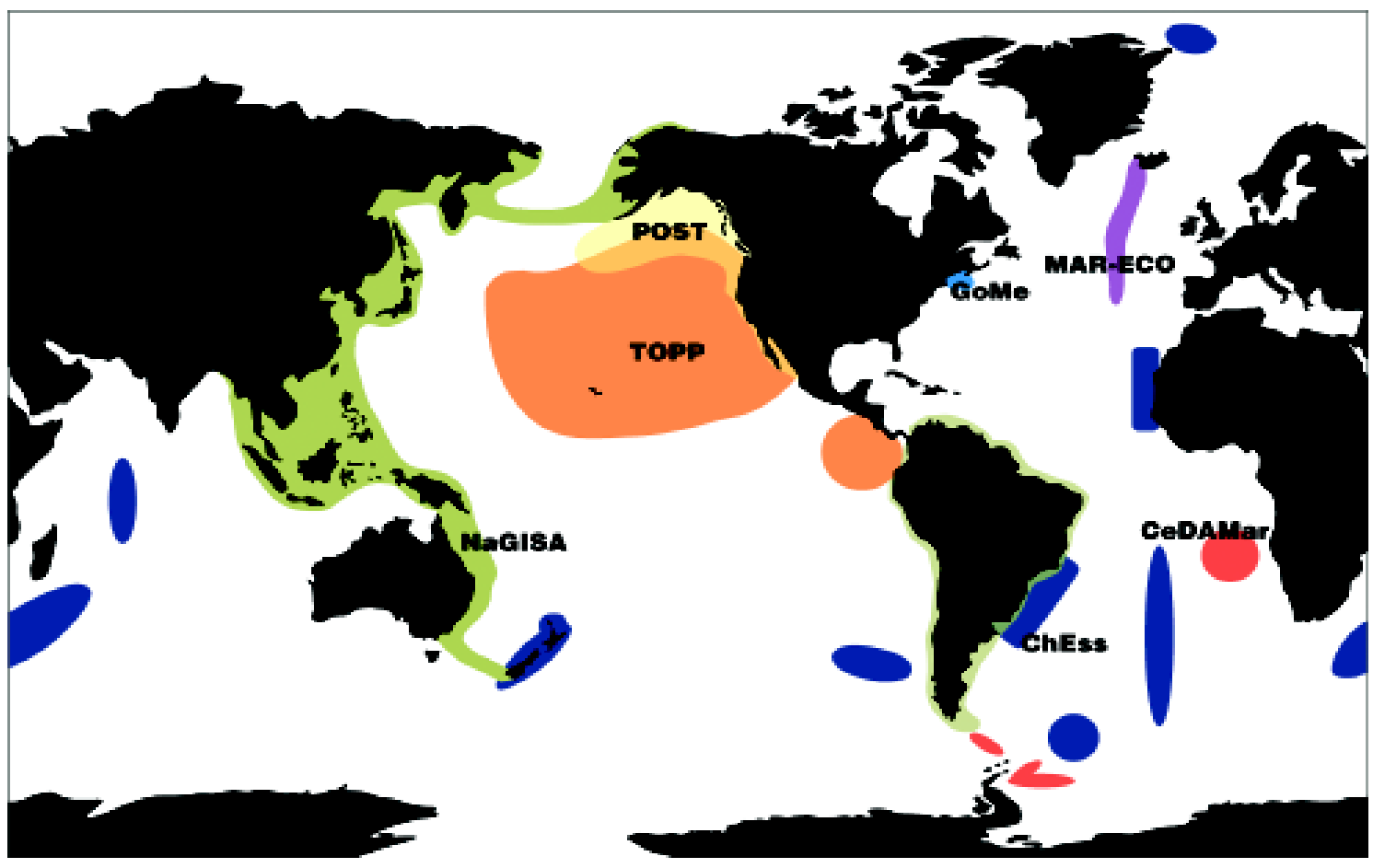

FIGURE 1. Global distribution of the seven planned CoML demonstration projects. Symbols indicate site of CoML workshop and meeting sites.

FIGURA 1. La distribución global de los siete proyectos de demostración planificados por CoML. Los símbolos indican los locales de los talleres y reuniones del CoML.

biodiversity. The first steps were the assembly of existing data and the development of a data management system to make this information accessible to scientists around the world. The next step was the development of a series of field studies to collect new information on life in the oceans. Finally, the use of these new and historical data will be combined with mathematical ecosystem models to provide predictions of the future state of marine communities.

In recognition of the need for reliable baseline information on marine ecosystems, the first project initiated by the CoML was the History of Marine Animal Populations (HMAP). Historians, ecologists and biologists formed an international consortium to 'rescue' historical records on changes in distribution and abundance of marine organisms before the era of modern fisheries management. This rescued history will create a new vision of ocean life as it existed before major human impacts and will provide a context for new information collected.
All of the data collected by the CoML would need a place to reside and remain accessible, leading to the establishment of the Ocean Biogeographic Information System (OBIS), a global network of interoperable databases. This internet-based, distributed system accesses not only species-level data on the distribution and abundance of living organisms but also on the chemical and physical characteristics of the environment in which they live. In addition, OBIS provides visualization tools to facilitate interpretation by all users of marine biological information. The online portal launched in early 2002 and has since successfully demonstrated the benefits of such a system. As it continues to link a growing number of taxonomic, environmental and fisheries-related databases, it will become a powerful tool for science, management, and education.

The SSC also supported the development of a series of initial field projects (Fig. 1) to demonstrate new quantitative approaches for sampling a full spectrum of life forms in the major ocean habitats. These 
projects are the initial phase in a series of projects to be conducted worldwide in a variety of habitats. All of the data from these-and future-projects will be assembled in and made available through OBIS. There are seven such initial projects underway. The project Natural Geography In Shore Areas (NaGISA) is intended to develop a simple, standardized approach to describe the biodiversity from the shore to a depth of ten meters at selected reference sites along coastlines (IBOY 2002). Much of the coastline around the Pacific is already planned, with the ultimate goal being to expand this project to similarly cover the millions of kilometers of coastline around the world.

The regional project in the Gulf of Maine (GoMe) brings together teams of U.S. and Canadian scientists to develop an integrated view of marine life and its environment in an already well-studied marginal sea, taking advantage of advanced technologies and monitoring systems already operating there.

The Mid-Atlantic Ridge Ecosystem project (MARECO) is addressing the challenge of measuring diversity and abundance in the water column of the deep ocean over one of the largest physical features in the ocean. This project will combine stateof-the-art sampling gear with high-resolution bathymetric surveys to characterize the communities and bottom topography along selected areas of the Ridge.

The most recently discovered and poorly characterized ecosystems associated with deep-sea hydrothermal vents, cold seeps, whale falls and wood debris are the targets for the Biogeography of Chemosynthetic Ecosystems project (ChEss). This study will examine already-discovered and new communities to form a global biogeographic understanding of their composition and distribution (Van Dover et al. 2002).

The abyssal plains are the largest habitat on the planet and the least well known. The Census of Diversity of Abyssal Marine Life (CeDAMar) project will explore benthic life in the deep basins, beginning in the South Atlantic Ocean. The abyssal plains may be the last place where science can study biodiversity patterns before major human impacts are felt.

Two projects in the Northeast Pacific use advanced telemetry techniques. These techniques make it possible for the animals themselves to report on their movements and the rapidly changing environments in which they live and on whose associated organisms they depend. The Pacific Ocean Salmon Tracking (POST) project uses coded acoustic tags in animals as small as 25 grams to record migrations along the highly productive continental shelf of western Canada and the U.S. The Tagging of Pacific Pelagics (TOPP) project uses satellite telemetry to track movements of large predators across the entire Pacific Ocean basin (Boustany et al. 2002). These new approaches should make it possible to identify and sample biological hot spots and to estimate abundances on ocean scales from limited, but strategic, direct sampling.

As mentioned, a Census of Marine Life is feasible today because of the emergence of new technologies for observing the ocean and the organisms that live there. The CoML is primarily interested in the implementation of technologies ready to be tested and calibrated in the field, rather than the development of new technologies. The initial field projects of the CoML demonstrate and integrate these quantitative sampling techniques to better reach areas of the oceans that have not been well sampled before. To assist, they work in collaboration with Working Group 118 of the Scientific Committee on Ocean Research (SCOR), which meets regularly to review and recommend new technologies for use in the field.

The final element of the CoML, the Future of Marine Animal Populations (FMAP), is focused on data management to maximize the coverage and precision of the data acquired through all elements of the program and to make available through OBIS the data and appropriate mathematical models. It was developed in response to the need for broader understanding of ecosystems to improve our ability to predict the biological impacts of climate change, harvesting, and other human interventions. However, to have any hope of predicting the unknown future, models must be able to predict the known past, so OBIS will also provide data and a testing ground for biodiversity, hindcasting using these tools.

\section{ORGANIZING THE COMMUNITY}

The oceans form a large global system in which biological, chemical, and physical processes are 
closely linked. Understanding biodiversity requires comprehensive coverage at various scales of both space and time. The goal of global coverage is fundamental to the CoML concept, not just the dream of over-ambitious scientists.

In order to achieve this goal, it is crucial that the CoML integrate with existing programs and form new cooperative efforts around the world to make the most efficient use of resources and to obtain the data needed to characterize life in the world's oceans. The CoML is actively seeking and building partnerships among the many national and international organizations, industry, and research programs to share information and collaborate on projects.

A worldwide research program aimed at collecting new information on marine species cannot be designed and implemented by a single central committee such as the SSC. To obtain global coverage from field programs, they must be developed on an ecosystem basis and funded at a local level. Therefore, the CoML is also supporting the formation of national or regional committees around the world to promote marine biodiversity research and to facilitate development of and support for new field projects: first at the national level in countries with major ocean research capacity to establish project and funding priorities, and second at the regional level to strengthen the collaborative efforts where large ocean areas are associated with countries having limited research capacity.

Canada, with CoML field projects on both its Atlantic and Pacific coasts, held a workshop in February 2002 to form a national committee. The major products were a review of existing biodiversity information in three oceans to meet commitments to the UN Convention on Biological Diversity and a commitment to incorporate the Department of Fisheries and Oceans Canada long-term survey data into OBIS. This proved a successful model, which Japan, Australia, the United States, and the European Union followed in the establishment of their national implementation committees.

The most advanced regional committee process has evolved from the joint meeting of the International Association for Biological Oceanography and the International Association for the Physical Sciences of the Ocean. This meeting took place in Mar del Plata, Argentina, in October 2001. A CoML Symposium there presented a series of papers
(Oceanologica Acta 2002) and laid groundwork for this South American Workshop on Marine Biodiversity, co-sponsored by the Partnership for Observation of the Global Oceans (POGO). South America is the first group of nations to organize regionally on behalf of the CoML. Similar regional efforts are now underway in Sub-Saharan Africa, Southeast Asia, the Indian Ocean, and the South Pacific.

\section{ACCESS TO INFORMATION}

Without access to accurate information about marine life and its environments, the scientific and societal needs to understand and predict the effects of changes in communities or habitats cannot be addressed. While contributing new knowledge, the CoML is building relationships with national and intergovernmental organizations, industry, and other groups already collecting taxonomically-resolved biodiversity information that should be made accessible through OBIS.

In 2001 OBIS became the marine associate for Global Biodiversity Information Facility (GBIF), established in Copenhagen under the Organization for Economic Cooperation and Development. In this role, OBIS will be the primary means of access to marine data for GBIF. The CoML is working closely with international and intergovernmental organizations, such as the International Council for Exploration of the Seas, the North Pacific Marine Science Organization, and the Food and Agriculture Organization of the United Nations. Efforts with these organizations should result in access to all the fisheries survey data available around the world. Industry is also an important retainer of marine biological information. The most successful collaboration that CoML has developed in this arena has been a joint effort between the Oil and Gas Producers Association Deep Water Environmental Taskforce and United Nations Environment Programme's World Conservation Monitoring Centre (WCMC). British Petroleum has agreed to provide all of its environmental data to the WCMC. An agreement between the WCMC and OBIS has begun the integration and linkage of this information through OBIS. A CoML investigator recently illustrated the value of scientific access to industry archives by discovering a new species of 10 
m-long deep-sea squid from videos generated by the oil and gas industry from around the world (Vecchione et al. 2001).

\section{SOCIETAL BENEFITS}

The concept for a Census of Marine Life grew out of scientific and societal recognition that declining biodiversity has been a consequence of climate change and human impacts on ecosystems. Good examples of direct economic impact from this decline, previously limited to the terrestrial realm, have become clear in the oceans and have called us to action to improve our knowledge of marine biodiversity. Other international ocean stakeholders also recognize this need and are beginning to integrate CoML biodiversity information for the management of commercial fisheries, conservation of marine habitats, and prediction of the potential impacts of climate change.

Single-species management of fisheries around the world has failed to provide sustainability because it does not accommodate the shift by fishermen from harvest of heavily exploited, regulated species to poorly studied species of lower trophic levels. Most major fisheries agencies are moving toward multi-species or ecosystem management, which requires information about the non-commercial and rare species - a focus of the CoML-and their function in their ecosystems. In many cases, there are no taxonomic experts available to these agencies to even describe the species making up the system with the detail required, let alone monitor it routinely.

One example of unanticipated effects of biocomplexity emerged from climate change studies such as the Global Ocean Ecosystem Dynamics Program. On Georges Bank in the Gulf of Maine, USA, blooms of planktonic jellyfish consumed small planktonic grazers that would normally have been food for larval fish. These blooms are thought to be related to changes in water conditions as a result of climate change; the impact of this on the future populations of adult fish are unknown (Madin et al. 1996). Under some conditions, such massive removal of species by large predators overwhelms changes in primary production and carbon dioxide fixa- tion that would have been predicted from the availability of sunlight and nutrients. In this case, the details of the biological diversity proved critical to understanding and modeling ecosystem performance.

The CoML is well prepared to provide special expertise to meet these newly-recognized needs in exchange for access to sampling opportunities. All new and existing data will be merged into OBIS. Cooperation with resource management agencies should increase the geographical coverage and, therefore, amount of information available for characterizing biodiversity patterns. As the amount of data, visualization tools, and FMAP model approaches accessible through OBIS increase, so will our ability to manage sustainable fisheries and to recognize and predict the effects of both natural and human impacts on ecosystems (Myers \& Worm 2003).

\section{THE FUTURE}

The primary goal of CoML is to explore, within the next decade, poorly known and even well studied areas of the world's oceans to gather reliable, quantitative data on the distribution and abundance of marine species, both new and already described. The knowledge collected will significantly increase our ability to understand the importance of marine biodiversity, past, present, and future. Other legacies of the CoML will also last far into the future. As long as it is maintained, OBIS will provide a single, easilyupdated entry point to a network of databases containing new and historical data and tools for interpreting the complex relationships between biology, geology, physics, and chemistry in the oceans. A second legacy will be a set of new sampling technologies and techniques, for use in both field and laboratory, and a set of analytical models that have been tested and calibrated for routine use in the assessment and explanation of marine biodiversity. In addition, they will provide an economical basis for ongoing biological monitoring, combining shipboard techniques with satellite and other modern ocean observation methods. The third legacy of CoML will be the working relationships that will have been established among all marine sectors and a recognition that it 
is to everyone's benefit to share our understanding of the oceans to better preserve them as the common heritage of humanity.

There are two ways in which the CoML expects to move forward on research activities -expansion of existing projects and development of new concepts for projects. Each of the seven initial field projects is demonstrating the use of a new technology or technique for collecting data on distribution, abundance, or diversity. Since the use of new technologies plays a key role in the projects that make up the CoML, the plan is to expand the sampling methods developed in these projects into other areas of the ocean. Thus, the initial development costs are borne by nations that have this capacity and expertise. Expansion of the projects will benefit other nations by providing tested methods and experts who can train others. Industry will benefit from the ability to sell technology that has been tested and approved for routine research use.

Expanded coverage of the ocean using the methods of the initial projects has already started. A funded prototype project in Australia, based on the POST approach and TOPP technology, is being applied in a corridor from the Cocos to Galapagos Islands in the South Pacific. The NaGISA project, initiated in the western Pacific, has been extended along Alaska and there is considerable interest to use the protocols along the coastlines of the contiguous United States and Antarctica. Adoption of CoML project approaches in South American research is a focus of this workshop.

The initial projects were designed to initiate and provide a basis for growth of the field phase of the CoML. They do not preclude the identification and support of additional new project concepts. There are still many habitats for which sampling approaches are lacking, and the CoML is eager to encourage the development of concepts for future support by the program. Project concepts are in development for marine observations under Arctic ice. A workshop to explore potential new projects on seamounts and canyons will be held in August 2003.

In order for the CoML to truly succeed, new field projects must be carried out in all regions of the world, with collaboration from many nations and organizations, using money, equipment, and ex- pertise from many sources. The CoML program has already significantly advanced scientific understanding based on its activities to date. To reach its full potential, however, it will require much more direct financial support of its field activities, as well as extensive collaboration to increase data assembly and new sampling opportunities. The new CoML national and regional implementation committees will be primarily responsible for identifying new project concepts, as well as promoting financial support from both traditional and non-traditional sources at the national levels. The efforts to create these committees are aimed at broadening interest in the program and in promoting the vision of distributed costs and responsibility.

Many areas of the oceans are unexplored and most of these are not geographically close to the nations with the greatest research capacity and expertise. For example, assessing the patterns of biodiversity will require much more effort in the Southern Hemisphere, since over $70 \%$ of the ocean habitat is located there and, thus, fewer countries. The CoML encourages the expansion of activities to the Southern Hemisphere through multi-national collaborations of those communities that will benefit most from the research. This South American Workshop on Marine Biodiversity is a major advancement toward the CoML goal of achieving a global perspective.

\section{REFERENCES}

Ausubel, J.A. 1999. Toward a census of marine life. Oceanography 12(3):4-5.

Ausubel, J.A. 2001. The Census of Marine Life: progress and prospects. Fisheries 26(7): 3336.

Boustany, A., S. Davis, S. Anderson, P. Pyle \& B. BLOCK. 2002. Satellite tags reveal expanded ecological niche for white sharks in the north Pacific. Nature 415(6867): 35.

International Biodiversity ObSERVATION Year. 2002. Biodiversity Research Methods: IBOY in Western Pacific and Asia. Kyoto University Press. Kyoto and Trans Pacific Press. Melbourne.

Madin, L.P., S.M. Bollens, E. Horgan, M. Butler, J. Runge, B.K. Sullivan, G. Klein-MacPhee, E. Durbin, A.G. Durbin, \& A. Bucklin. 1996. Voracious planktonic hydroids: unexpected predatory impact on a coastal marine ecosystem. Deep Sea Research II 43: 1823-1830. 
Gayana 67(2), 2003

Myers, R.A. \& B. Worm. 2003. Rapid worldwide depletion of predatory fish communities. Nature 423: 280

National Research Council, Committee on BiologiCal Diversity in Marine Systems. 1995. Understanding Marine Biodiversity. National Academy Press. Washington, DC.

Oceanologica Acta, Special Issue. 2002. 25(5).

Van Dover, C.L., C.R. German, K.G. Speer, L.M. ParSON, \& R.C. VRIJENHOEK. 2002. Evolution and biogeography of deep-sea vent and seep invertebrates. Science 295: 1253 - 1257.

Vecchione, M., R.E. Young, A. Guerra, D.J. Lindsay, D.A. Clague, J.M. Bernhard, W.W. Sager, A.F.F. Gonzalez, J. Rocha, \& M. Segonzac. 2001. Worldwide observations of remarkable deep-sea squids as calibrated technologies and protocols are adopted in many regions. Science 294: 250 .

Fecha de recepción: 06/05/03

Fecha de aceptación: 12/09/03 